\title{
The Effectiveness of No Smoking Area Implementation In UPN "Veteran" of East Java
}

\author{
$1^{\text {st }}$ Fauzul Aliwarman \\ Civil Law Department, Faculty of Law \\ UPN "Veteran" \\ Surabaya, Indonesia \\ fauzula.ih@upnjatim.ac.id
}

\author{
$2^{\text {nd }}$ Eko Wahyudi \\ Civil Law Departement, Faculty of Law \\ $U P N$ "Veteran" \\ Surabaya, Indonesia
}

\begin{abstract}
Smoking activity in the academic community in the campus environment has become habit that is considered as unhealthy and less educating for the education environment. The effort to build cigarette-free campus is intended as campus where there is no activity related to smoking for the better development of future generations. Ironically, the cigarette-free campus existence without is still far from expectations and just rhetoric of the leaders and management. Of course this causes discomfort and unrest in the campus in providing healthy space for the attending academic community. The campus as barometer that produces young Indonesian intellectuals that prioritizes the character building of youth has interest in providing legal protection and advocacy and healthy environment. The problem is the lack of regulatory support for realization of no smoking area in UPN "Veteran" of East Java. It need socialization about the smoking effects and the right of passive smoker to get healthy environment in the campus area for all academicians, supervision forms and sanctions enforcement for offenders not to smoke and support the college management alignments in encouraging the campus without cigarette for the academic community.
\end{abstract}

Keywords-Effectiveness, No Smoking Area, Cigarette

\section{INTRODUCTION}

Smoking activity in the academic community in the campus environment has become habit that is considered as unhealthy and less educating for the education environment. This habit can bring death and misery to the perpetrator. WHO data says five hundred adults die because of these unhealthy habits. Even predicted in 2030 or faster one in six people will die because of smoking.

Data from National Survey in 2004 stated that $63.2 \%$ of Indonesian men and $4.4 \%$ of women were smokers. Overall (men and women combined), more than $30 \%$ of Indonesia's population smokes, meaning that in our country there are around 60 million smokers.

Smoking for young generation has become symbols of pride or maturity. Now it is not new if the young generation smokes and addicted to cigarettes. Most young generation start smoking because their friends, apart from being influenced by image created by cigarette manufacturers (for example, by using teen idols as advertising stars) or because they have smoking parents. Various factors triggering the smoking rate increase in young generation are large-scale advertising and promotion from the tobacco industry, easy access to cigarette products, and affordable prices.

"Veteran" National Development University of East Java as one of the campuses in Surabaya City where the teaching and learning process of the nation's children has been declared as campus that implements no smoking area. It is necessary, conducted surveys and research that can provide a more accurate picture in order to provide input for policy makers and relevant units in implementation of no smoking area in Veteran National Development University of East Java. Based on the description above, the problems of the study are as follows, how effective is the implementation of no-smoking areas in UPN "Veteran" of East Java?

\section{RESEARCH METHODS}

Research on the effectiveness of implementation of nonsmoking areas in UPN "Veteran" of East Java is empirical juridical research or non-doctrinal legal research. This type of research is also called sociological legal research (social legal research ) in this research, weigh against the work of law in the community [1].

This type of research is carried out by reviewing and processing research data obtained directly in the field, which are primary data or also called field research with starting point on legal aspects (juridical). To support and complete primary data, library research is conducted to obtain secondary data about research problems[2]. In other words, the data used in this study are primary data and secondary data.

All data have been collected exhaustive research, both obtained from library research and field research then be processed and analyzed qualitatively. Qualitative analysis is carried out by observing facts that actually occur in the field. Research data that have been analyzed further compared to secondary data or norms that should be valid, then concluded by using deductive thinking method, which is based on general theory or concept (applied) to explain the relationship of a data with other data.

The research results obtained will be compiled in final report of descriptive research to provide real picture of the implementation effectiveness of no-smoking areas in the Veteran National Development University of East Java.

\section{RESULTS AND DISCUSSION}

Realization of the implementation of no-smoking area in Campus of UPN "Veteran" of East Java which has been effective since 2011 needs to be reviewed and evaluated to see the program effectiveness. This program is based on research results supported by almost $71.9 \%$ academic community who want the realization of no smoking campus that really runs on UPN "Veteran" of East Java. Only $26.3 \%$ of the academic community stated that they refused to implement the program. 
Assessing the effectiveness of the implementation of nosmoking areas in UPN "Veteran" of East Java is closely related to awareness and adherence of academic community to the applicable legal provisions. In other words, if rule of law is adhered by campus academic community, then it can be said that the rule of law has been effective.

The legal compliance level of the academic community of UPN "Veteran" East Java can be seen from the legal compliance theory according to Achmad Ali[3], CG Howard and R. S Mumners as follows:

\section{A. Relevance of general law rules with the legal needs of the people who are the rule target.}

If the intended one is the regulator or legislators, in this case the university senate, the regulators are required to be able to understand the legal needs of the regulation enactment target, the academic community. Based on the study results it was found that there were no specific university rules in the form of rector regulations or other technical instructions on smoking bans in campus.

However, according to the author's opinion, it should be that UPN "Veteran" of East Java as campus organization embodies the No-smoking Area rule contained in Government Regulation No. 109 of 2012 concerning safeguarding for materials containing addictive substances and Surabaya City Regulation Number 5 of 2008 concerning No Smoking Areas and Limited Smoking Areas in separate regulations. Includes arrangements with additional technical matters. Thus, the regulation of no-smoking areas can be used as reference and basis for implementation of the clear and measurable sanctions toward violations occurred and the legal umbrella for law enforcement toward violations occurred at the faculty level. As Hans Kelsen in his theory explains that legal norms are tiered and layered in structure hierarchy. Legal norms are always based the norms above, but downward legal norms also become sources and become the basis for lower norms.

With current conditions, the no-smoking area implementation in UPN "Veteran" of East Java can still refer to the general regulations on no-smoking areas in the Surabaya City Regulation No. 58 of 2008 concerning No Smoking Area and Limited Smoking Area and Article 3 (2) letter a Surabaya Mayor Regulation No. 25 of 2009 concerning Implementation of Surabaya City Regulation No. 58 of 2008 concerning Nosmoking Areas and Limited Smoking Areas. However, in terms of law enforcement for violations of no-smoking areas in the UPN "Veteran" area of East Java become ambiguous and cannot be done. This is constrained due to the lack of clarity in responsible apparatus, field monitors and field implementers and the sanctions level given.

\section{B. Clarity from the substance formulation of the rule of law, easy to understand.}

The substance formulation of the rule of law must be well designed. If the rules are written, it must be written clearly and easily understood. Although later it will use interpretations from law enforcers who will implement it.
The results showed $80,7 \%$ of respondents could understand the rules of no-smoking areas in the campus of UPN "Veteran" of East Java well, $10.6 \%$ of respondents said they did not understand and $6,98 \%$ of respondents said they were hesitant. So the rules of procedure are considered effective in guiding the academic community obey to the applicable law even though it is still in the realm of Surabaya City Regulation No. 58 of 2008 concerning No-smoking Areas and Limited Smoking Areas.

\section{Optimal socialization to all communities.}

Forbidding regulations are seen as better than those that require with reason the forbidding regulations are easier to implement than regulations that require them[4].

The results showed majority of respondents $71.9 \%$ stated his agreement with the determination of East Java UPN as one of the No-smoking Campus Areas in Surabaya. While other $18.6 \%$ claimed as did not agree with the determination. The remaining $7.7 \%$ stated that they refused or did not agree with the determination of the No Smoking Area Campus. Thus, it can be said that generally the academic community supports the existence of UPN "Veteran" of East Java as campus without cigarettes.

The socialization media that is considered the most effective in socializing is through the installation of smoking signs /instructions /restrictions on the campus area of UPN "Veteran" of East Java. The majority (58.9\%) of respondents claimed to know the smoking ban arrangement from seeing the smoking ban signs /instructions /warnings installed in the campus area. While $37.7 \%$ stated there was no view of smoking ban signs /instructions /warnings installed in the campus area. Only about $1.97 \%$ of respondents expressed other opinions.

Another form that is important equally with the rule socialization success is the emergence of support and awareness from the academic community to always remind other academician not to commit violations while in the campus. Most of the respondents (57.39\%) admitted that the effort to remind smokers not to smoke so far has been unsuccessful. Even $34.47 \%$ of other respondents stated explicitly that the reaction of smokers who were reminded not to smoke while in the campus without smoking was not successful at all. Only $7.53 \%$ of UPN East Java respondents stated that efforts to remind these smokers not to smoke in no smoking areas were considered successful.

The socialization success influenced by the academic community's attitude against the rules that will determine the effectiveness of the regulation implementation. If most people behave negatively, meaning they will not obey these rules and possibly many offenses if applicable [5]. The behavior toward the smoking risks of adults are affected by their parenting during childhood. The more afraid to smoking risks, the less they will smoke. Authoritative parenting will make the child's behavior little smoking [6]. 


\section{The severity of sanctions that are threatened must be proportional and possible to be implemented.}

Too heavy sanction difficult to implement and can make injustice instead of too light sanctions make the law purpose not achieved and the nature of deterrence is not functioning, so people will not hesitate to commit crimes or violations [3].

The results showed that the majority $(78.2 \%)$ of the academic community respondents of UPN "Veteran" of East Java admitted that they did not know the sanctions form that would be imposed on violators of No Smoking Areas. Only small percentage of them $(9.84 \%)$ were aware of the sanctions threat for violators. The remaining around $10.6 \%$ of respondents said they were hesitant about whether there is sanction threat or not.

Academic community knowledge towards these sanctions is directly proportional to the lack of directives or instructions installed on campus. The respondents majority (84.3\%) of the UPN "Veteran" of East Java admitted that they had never seen any form of sanction in public places that would be imposed on violators of the No Smoking area. Only small number of respondents $(13.1 \%)$ said they saw sanctions threat for violators in public places in the campus area. The remaining around $1.25 \%$ of respondents said they were hesitant about whether or not there was sanction threat.

While the results of interviews with the Deputy Chancellor for general and finance explained that to date there have been no university rules or technical guidelines regarding smoking bans on campus as a reference in action, including sanctions.

\section{E. Enable the law enforcer to process if there is the rule of law violation.}

Violations committed by the perpetrators bring logical and decisive consequences for sanctions threat that have been regulated. The sanctions implementation is concrete action to enforce the rules that have been enacted and passed[7].

Even though UPN "Veteran" of East Java does not have an independent regulation regarding the no smoking area, but if it refers to Article 8 paragraph 2 of the Surabaya Mayor Regulation No. 25 of 2009 concerning the Implementation of Surabaya City Regulation No. 58 of 2008 concerning NoSmoking Area and Limited Smoking Area stated that each leader or person in charge of the learning process place as referred to in Article 3 paragraph (2) is obliged to give warning, reprimand and / or take action to every student, educator and education staff or every people who are in the area where the teaching and learning process is their responsibility if proven they carry out these activities.

The results showed that almost half (49\%) of respondents in UPN "Veteran" of East Java admitted that they had never seen officers or leaders rebuked offenders who smoked or did not smoke in campus area. This data is strengthened again from $37.9 \%$ of respondents said it is very rare to see officer or leader admonishing the offenders who smoke or not to smoke in this campus area. Only few (11.6\%) stated that they often saw officers or leaders who were committed to reprimand the offenders who smoked or not to smoke in the campus area of UPN "Veteran" of East Java.

This data is directly proportional to practice of giving administrative sanction which are further sanctions if the warning sanctions do not have positive effect. The majority $(77.5 \%)$ of respondents from UPN "Veteran" of East Java claimed to have never seen or found out that officers or leaders gave administrative sanctions for offenders not to smoke anymore. While $15.4 \%$ of other respondents said they rarely saw or knew of any officers or leaders who gave administrative sanctions for violators in no-smoking areas in UPN East Java. Few (5.72\%) of respondents said they had seen or knew of officer or leader giving administrative sanctions for the offender.

It was also revealed that most $(50.6 \%)$ respondents of the UPN East Java academic community admitted that they were hesitant about the commitment and courage of officers or leaders in cracking down smokers who smoked in this nosmoking campus area. Even more than $31.1 \%$ of respondents stated unanimously that officers or leaders did not have the commitment and courage to take action against violations in this no-smoking area. Only $16.8 \%$ of respondents who still believe officers or leaders still have the commitment and courage to take action against cigarette offenders in the East Java UPN "Veteran" campus area .

Sanctions form that are still common and not measurable, will later have impact on the likelihood that the offender will be completely free from the law[8]. Those who have authority in enforcing sanctions are also not clearly regulated, so that it is feared that in the future the interpretation of existing rules will differ depending on the interests behind it.

In the author opinion, the violations handling should be carried out by a legal, credible and patterned disciplinary unit committee and can provide legal decisions related to actions that must be taken. While the security unit is tasked with reminding or reprimanding any violations.

\section{F. Legal rules that contain moral norms in the form of prohibitions, will be relatively more effective than legal rules that are contradictory or not regulated as moral norms.}

The results showed the majority $(61 \%)$ of respondents claimed to feel comfortable and helped by the existence of nosmoking Campus Program at UPN "Veteran" of East Java. While $17.5 \%$ of other respondents felt uncomfortable with the determination of UPN "Veteran" East Java as one of the No Smoking Areas in the City of Surabaya. The remaining 19.5\% of respondents said they did not want to respond by setting a no-smoking area on the campus of UPN "Veteran" East Java.

However, academic community experience in this survey expressing their dissatisfaction with the program implementation of No Smoking at UPN "Veteran" of East Java. Most (46.3\%) of respondents admitted that the implementation of No Smoking Campus Area program at UPN East Java was considered very unsatisfactory. Plus $39.36 \%$ of the other respondents explicitly stated that they 
were not satisfied with the implementation of the No Smoking Area program on the campus of UPN "Veteran" East Java. Only $12.8 \%$ of the remaining respondents still stated the value of satisfaction in the implementation of No-smoking Areas in this campus.

Thus, the prohibition rules for the academic community of UPN "Veteran" of East Java for not smoking while in campus provide more comfort. The study results are positively correlated with the feeling of dissatisfaction among the academic community when the existing rules are not enforced and the offender is not sanctioned.

\section{G. Optimality and professionalism of law enforcement} officials in enforcing the rule of law in general.

Sociologically, between the rule of law and law enforcement are two different things. Legal rules, including laws and the various legal principles that underlie it, are abstract, whereas the implementation of law including the operation of sanctions is concrete one. The link between the abstract and concreteness in law enforcement is law enforcer, especially the party appointed or trusted to do punishment.

Every law enforcer sociologically has position and role. Position is a certain position in the social structure that may be high, medium or low. This position is container whose contents are certain rights and obligations[9]. These rights and obligations are role. Therefore, a person has certain position usually called the role holder. A right is actually an authority to do or not act while an obligation is burden or duty.

Law enforcers in the context of campus life are individuals or bodies stated by regulations (regeling) or provisions (beschiking) of the university leaders in taking action against every perpetrator who commits an offense. Acquisition of research results shows that institutions or individuals who are given authority in conducting supervision and prosecution are not yet clear because there are no written decisions. However, on several occasions the weekly rally the Rector orders the faculty leaders to supervise and suppress the academics community who violate the program. If drawn further, the faculty leader is the person in charge for the activities of their unit's activities. That way, this is in line with the affirmation of Article 8 of the Surabaya Mayor Regulation No. 25 of 2009 concerning the Implementation of the Surabaya City Regulation No. 58 of 2008 concerning No-smoking Areas and Restricted Areas Smoking every leader or person in charge of the learning process place must prohibit, give reprimand and warnings and or take action against every student, educator and education personnel who commit violations.

The results showed that almost half of the respondents of the academic community of UPN "Veteran" East Java $(49.73 \%)$ admitted that the implementation of No-smoking Campus Area in UPN East Java had only been applied for a part and seemed not serious. Even $38.64 \%$ of the other respondents expressly stated their judgment that the no smoking area had not been implemented properly and seriously in the campus of UPN "Veteran" East Java. Only $7.87 \%$ of respondents stated that the implementation of No- smoking Areas in UPN East Java was implemented properly. Other respondents $(1.9 \%)$ expressed other opinions. The lack of student satisfaction is in line with the absence of supervision and repression of violations that have occurred on campus in the past six years.

Professionalism and optimality of the implementation of the role, authority and function of law enforcer, is not enough only in the field of law enforcement. However, it must also be seen from the side of how they carry out the tasks assigned to them[4].

The results showed that, the management of daily tasks and responsibilities division and the performance achievement in the program of no-smoking areas in UPN "Veteran" of East Java was not satisfactory in terms of the indicators above.

\section{CONCLUSION}

Based on previous description, there are some conclusions as the closing of this paper as follows: the implementation effectiveness of no-smoking areas in UPN "Veteran" of East Java in the past 7 (seven) years was considered ineffective, as evidenced by the number of indicators that were not met. The fulfillment of all components in the theory of obedience to the law which became the standard for measuring the effectiveness of a rule of law

Obstacles encountered in the implementation of no smoking campus are at the lack of readiness of UPN "Veteran" of East Java arranging implementing rules, human resources and culture that have been rooted before.

\section{ACKNOWLEDGMENT}

Thanks to God, for the blessing, mercy, health and guidance in leading our research to finish. We are really grateful to:

1. The Dean of Law Faculty of UPN "Veteran" East Java who has given his permission to conduct the research.

2. The Lecturers of Law Faculty of UPN Faculty "Veteran" who always supports and encourages her to accomplish the research.

The writers realize that research is far from being perfect. Therefore the writers will be delighted to accept every comment and suggestion. Hopefully, the research will be beneficial for everyone who reads it and those who are concerned with the research.

\section{REFERENCES}

[1] B. Sunggono, Legal Research Methodology. Jakarta: Rajawali Press, 2003

[2] Supranto, Legal and Statistical Research Methods. Jakarta: Rineka Cipta, 2003.

[3] A. Ali, Open the Law Screen. Bogor: Ghalia, 2011.

[4] S. Mertokusumo, Knowing Introduction Law. Yogyakarta: Liberty, 2003. 
[5] R. C. and M. Utamo, "Factor That Influence University Students' Attitute Toward Smoking Prohibition," Adv. Soc. Sci. Educ. Humanit. Res., vol. 139, pp. 34-40, 2017.

[6] M. Arifin, "On Perceived Risk Perception Toward Smoking Behavior and Parenting Style As Predictor Of Smoking Risk Behavior In Adolescents," Adv. Soc. Sci. Educ. Humanit. Res., vol. 1, no. 27, pp. 273-276, 2017.
S. Soekanto, Factors Affecting Law Enforcement. Jakarta: Rajawali Press, 2011

[8] M. Fuady, Critical Law School; Paradigm of Law Impotence. Bandung: Citra Aditya Bakti, 203AD.

[9] S. Rahardjo, Law Rahardjo. Bandung: Citra Aditya Bakti, 2000. 